\title{
Empirics of Agricultural Production: Comparison of Instrumental Variable and Two Stage Least Square Approach
}

\author{
Asif Warsi \\ Iqra University \\ Dr. Amena Sibghatullah \\ PAF KIET University \\ Dr. Athar Iqbal \\ Iqra University
}

\begin{abstract}
The study uses datafor a set of 81 countries from World Development Indicators from year 2002 to 2015 while applied 2SLS and Instrumental variable approach to estimate the coefficients associated with standard production function of agricultural production and compares its results with the coefficients obtained through OLS. The argument behind this approach that in the standard form, capital is likely to be endogenous in the production function and if it is true, the coefficients obtained through OLS would be inconsistent. Capital is found to be endogenous in the study. It is also noticed as endogeneity exist in our framework and the causal relationships can be controlled through instrumental variable approach (I.V.). The coefficients from I.V approach and 2SLS are compared with OLS estimates. I.V and 2SLS coefficients are found to be slightly different however, the obtained coefficients through both approaches are more reliable then the coefficients obtained through OLS. It is suggested therefore that the approaches like I.V approach and 2SLS should be employed in the studies pertaining to this area of research.
\end{abstract}

Keywords: Agriculture, Physical Capital, Instrumental Variables (IV), Endogeneity/2SLS

\footnotetext{
1.asifwarsi@gmail.com,

2. amenasibghat@gmail.com,

3. athar@iqra.edu.pk
} 


\section{INTRODUCTION}

There has been extensive literature available that discusses the contribution of agricultural productivity in addressing various macroeconomic problems such as growth, development and poverty reduction. This sector is the oldest sector of economic history and the most important sector for under developed and developing countries of the world.

The empirical literature on this subject starts from Heady (1946) that starts the discussion on the empirics of agricultural production in general and the production functions in the agricultural sector in particular. The possible reasons of heterogeneous agricultural productivity across the world is enlightened in Bhatta charjee (1955) through cross country data for the first time. Some of the influencing empirical studies includes Heady and Dillon (1961), Hayami (1969), Hayami and Inagi (1969) and Hayami \& Ruttan (1971) that illuminate the factors which are responsible for huge differences in the agricultural productivity across countries.

There are various studies for instance Trueblood and Ruttan (1995), Hayami and Ruttan (1970), Kawagoe et al. (1985) and Lau and Yotopoulos (1989) which employ Meta production functions for estimating multi-factor productivity. Vollrath (2007), Mundlak et al. (2008), and Mundlak (2012) are some of the current empirical studies that illuminate the diverse issues pertaining to the area of agricultural productivity.

The past studies employ different production functions to estimate the relative importance of different inputs in the agricultural production however the studies could not check the possible endogeneity in the standard production function using labor and capital as production inputs (Brückner, 2012). Since, in the general form, production depends on labor and capital whereas more production (income) induces more investment in the economy thus "capital' as input in the production function is a strong suspect to be endogenous and if it is true, then the coefficients obtained through ordinary least square would be biased and inconsistent. The study tests the possibility of endogeniety in the production function and compare the estimates obtained through ordinary least square with the one obtained through the alternate procedures appropriate in the presence of endogeniety.

The section 2 of this paper presents a brief review of the past studies, section 3 presents methodology and estimation andsection 4 discusses the implications of the findings and concludes the discussion.

\section{REVIEW OF LITERATURE}

Fulginiti and Perrin (1998) examine productivity changes in the agriculture sector through the annual dataset from 1961 to 1985 for 18 developing countries. The study uses a Cobb Douglas production function having land, labor, fertilizer, machinery and livestock as inputs in the process of agriculture production. The presence of variable 'machinery' is used for capital which should have been tested for endogeniety. A decline in agricultural productivity was found in around 9 of the countries in the sample. The study also found a negative effect of agriculture tax on 
IBT Journal of Business Studies (IBT-JBS) Volume 15 Issue 2 December 2019

agro-productivity.

Mundlak et al. (1999) employed canonical regression analysis to enlighten the determinants of agricultural productivity by using a data set of 37 countries. The study found capital as relatively important factor in the productivity determination and the finding is found to be consistent in various modifications in the original model including the desegregation of capital into two components. The study also found that the agriculture sector is more cost intensive as compared to the nonagriculture sector however, the core as well as the subsequent analysis was carried out without considering the possibility of endogeniety in the production function which poses questions on the un-biasness of the estimated coefficients.

Felloni et al. (2001) uses a dataset of 83 countries to study the role of infrastructure in the agriculture production and their implications for China. The study found that value of agricultural production is significantly link with the production in the transport and energy sector whereas land productivity is found to be linked with roads and electricity. The electricity consumption per agricultural worker is found to be a positive and significant factor for labor productivity for the countries in the sample.

Ogunyinka and Langemeier (2004) illuminate the difference in agricultural productivity through a data set of 125 countries from 1961 to 2001 . The study found that technological change is the key determinant of productivity growth in the developed countries. Change in efficiency is found to be negative in the developed countries whereas technological change is found to be negative in the developing countries. The lack of productivity in the developing countries was found to be the main cause of declining world productivity for most of the period in question.

Alauddin et al. (2005) uses a dataset of 111 countries for the years 1970-2000 to estimate total factor productivity in the agriculture sector through cross sectional and panel regressions. The study examines the contribution of environmental, geographical economic and other related factors in determining the level of total factor productivity across countries. The study found human capital, openness and environmental factors as key determinants of agricultural production. The study performs detailed analysis on the subject however the production function used in the study is in the form of a single equation which is not tested for the possible endogeniety which weakens the results presented in the study. Later on Heady at al. (2010) uses a dataset of 88 countries over the 1970-2001 to estimate total factor productivity in the agriculture sector through stochastic frontier analysis (SFA) and data envelopment analysis (DEA), and founds that stochastic frontier analysis (SFA) shows better and more reliable results than data envelopment analysis (DEA).

Winters et al. (2010) empirically examines the pattern of rural development and proposes a pattern of development with less dependence on agricultural production. The study uses micro mega dataset having more than 70,000 observations from 15 developing countries. They study found positive relationship between per capita income of rural households and the share of income from the non-agricultural wage in an economy. Moreover, the countries with higher GDP per capita were 
found to have a shift to non-agriculture wage employment then the other countries implying that the effect becomes stronger with economic development, a negative relationship also founds in between per capita income and agricultural production.

Mundlak et al. (2008) uses an annual dataset from 30 countries for the period 19722000 to estimate agricultural production function. The study estimates agriculture production as a function of agricultural technology and the state of economy whereas a heterogeneous technology framework is used to capture the effect of technology in agricultural production. The study found that total factor productivity accounts for around 59 percent of overall growth. Most of the remaining part of growth is found to be associated with large inflows of fixed capital in the agriculture sector. Like the other studies in the subject, the study could not account for the possibility of possible endogeniety of the variable "Technology" used in the analysis which could be endogenous in the same way as the variable capital used in the other studies.

Headey et al. (2010) examines the determinants of total factor productivity growth by using the dataset of 88 countries overthe period 1920-2001. Government policies, institutional variables, including public expenditure and pro-agricultural price policy reforms were found to be significantly related with TFP growth. The policy variables were endogenous in themodels with both reverse causality from productivity to policies however, the endogeniety of capital in production process is not taken into account in the analysis.

Gollin et al. (2014) found misallocation of labor force in the agriculture sector as the major cause of declining labor productivity in the developing countries. The study uses hours worked and human capital per worker by sector, urban- rural cost of living differences, and alternative measures of value added per worker as the determinants of agricultural productivity in the developing countries. In light of the findings, the study recommends a shift of labor from agriculture to non agriculture sector in order to increase productivity.

Lagakos and Waugh (2013) studied the differences in labor productivity of agriculture and non agriculture sector. It was found that in the poor countries, the labor productivity is low and opposite is the case of rich countries where the worker in agriculture sector is found to be more productive as compared to his counterpart in the poor countries. Though the productivity difference is found to be clear in poor and rich countries in agriculture and non agriculture sectors however, it is found to be much greater in the agriculture sector.

Allen and Qaim(2012) studies the role of different types of social services that affect the efficiency of agricultural production using a data set from 1961-2010 for Sub-Saharan Africa. The study adopted Frontier Analysis and a Structural Equation Model to access the role of social services in the efficiency of agricultural inputs. The study found that education and health expenditures are the most important factors that influence the agricultural productivity in Sub-Saharan African countries. Despite the extensive analysis on the subject, the study does not keep the possibility of endogeneity in the production function in consideration and uses a single equation function which may have led to provide biased estimates pertaining Page | 65 
to agricultural productivity.

\section{METHODOLOGY AND ESTIMATION}

The study uses a Cobb-Douglas production function to estimate the significance and relative magnitudes of the inputs in the agriculture sector. The production function with three inputs is stated as follows:

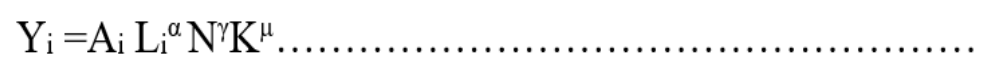

Where Yi is the agricultural production of country i, measured in constant 2000 US dollars. Li represents Agricultural land for country i measured in square kilometers. $\mathrm{Ni}$ is the labor input in agriculture sector whereas $\mathrm{Ki}$ is the use of capital in the agricultural production captured through agricultural machinery (Tractor) whereas $\mathrm{Ai}$ is the total factor productivity for country $\mathrm{i}$. The data for all variables is taken from World Development Indicators (WDI). The data is taken from year 2002 to 2015 and the average values for the variables are used in the estimation.

The log transformed form of equation to be estimated as follows:

$$
\log \left(\mathrm{Y}_{\mathrm{i}}\right)=\mathrm{a}+\alpha \log \left(\mathrm{L}_{\mathrm{i}}\right)+\gamma \log \left(\mathrm{N}_{\mathrm{i}}\right)+\mu \log \left(\mathrm{K}_{\mathrm{i}}\right)+\varepsilon_{\mathrm{i}}
$$

The specification in the equation 1.1 is similar to the previous studies and the variable ' $\mathrm{K}$ ' is a possible candidate for endogeneity. Theory postulates that more capital leads to produce more output whereas more output (income) induces more saving thereby increases the flow of capital. If this relationship significantly exists in the data, the coefficients of equation 1.1 would be biased and inconsistent. It is necessary therefore to check endogeneity prior to estimating equation 1.1. Moreover, Sovey \& Green (2011) further presented their views on the instrument

\section{Test of Endogeneity}

The two stochastic specifications in the general regression framework is that the conditional expectation of $\mathrm{U}$ given $\mathrm{X}$ be zero (or for fixed $\mathrm{X}$, $\mathrm{u}$ have expectation zero) and that $U$ have a spherical covariance matrix. Mathematically;

$$
\begin{aligned}
& \mathrm{E}(\mathrm{u} \mid \mathrm{X})=0 \\
& \mathrm{~V}(\mathrm{u} \mid \mathrm{X})=\sigma^{\wedge} 2
\end{aligned}
$$

First expression represents orthogonality condition while the second is referred to as sphericality condition. If the condition one violates, the obtained coefficients would be biased and inconsistent while the violation of second assumption leads to inefficient estimators eventhough the estimator remains unbiased Hausman (1978).

To check the possibility of endogeneity in the equation 1, the version of Hausman test proposed by Davidson and MacKinnon $(1989,1993)$ is employed. In the first step of this test, OLS is applied on the following model.

$$
\log \left(\mathrm{K}_{\mathrm{i}}\right)=\beta_{0}+\beta_{1} \log \left(\mathrm{L}_{\mathrm{i}}\right)+\beta_{2} \log \left(\mathrm{N}_{\mathrm{i}}\right)+\beta_{3}\left(\mathrm{~F}_{\mathrm{i}}\right)+\mathrm{U}_{\mathrm{i}}
$$


As suggested by Davidson and MacKinnon $(1989,1993)$, the potentially endogenous variable $\mathrm{Ki}$ is regressed against all exogenous variables including the instrumental variable Fi.In the next step, The following equation is used.

$\log \left(\mathrm{Y}_{\mathrm{i}}\right)=\pi+\alpha \log \left(\mathrm{L}_{\mathrm{i}}\right)+\beta \log \left(\mathrm{N}_{\mathrm{i}}\right)+\gamma \log \left(\mathrm{K}_{\mathrm{i}}\right)+£ \log \left(\mathrm{F}_{\mathrm{i}}\right)+\psi \mathrm{U}_{\mathrm{i}}+\mathrm{C}_{\mathrm{i}} \ldots \ldots \ldots$

In this model Uiis the residual of model used in the step one, for the country $i$. If the coefficient $\psi$ is insignificant, it will indicate that the model 1 is consistent (and $\mathrm{Ki}$ is not endogenous). If $\psi$ is significantly different from zero, it implies that the residual of $\mathrm{Ki}$ is included as a factor in explaining $\mathrm{Yi}$ and $\mathrm{Ki}$ is not exogenous. The result of final step is presented in the table 1 .

\begin{tabular}{|c|c|c|c|}
\hline \multirow{2}{*}{ Independent variables } & \multicolumn{3}{|c|}{ Regression with instrumental variable and residual of auxiliary } \\
& regression & \\
\cline { 2 - 4 } & Coefficient & Std. Error & Probability \\
\hline $\mathrm{L}$ & 0.567 & 0.064 & 0.000 \\
\hline $\mathrm{N}$ & 0.278 & 0.065 & 0.000 \\
\hline $\mathrm{K}$ & 0.133 & 0.081 & 0.105 \\
\hline $\mathrm{F}$ & 0.385 & 0.077 & 0.000 \\
\hline $\mathrm{U}$ & 0.000 & 0.000 & 0.098 \\
\hline $\mathrm{C}$ & 9.386 & 0.749 & 0.000 \\
\hline Adjusted R2 & 0.839 & & \\
\hline F-Statistics & 84.407 & & \\
\hline Prob(F-stat) & 0.000 & & \\
\hline
\end{tabular}

All variables are in log form'

Note: Dependent variable is the Value added of agriculture sector (constant 2000 US dollars)

Source: Authors' estimation

In this case, the hypothesis of consistent estimates can be rejected at 10 percent implies that the variable $\mathrm{Ki}$ is endogenous and the obtained coefficients of equation 1.1 are inconsistent. To overcome this issue, there are alternative methods such as instrumental variable approach; two stage least square approach. The necessary details of the approaches along with the estimated coefficients are presented in the subsequent sections. 


\section{Instrumental variable approach}

The variables and the functional form of production function used in this study is:

$$
\log \left(\mathrm{Y}_{\mathrm{i}}\right)=\pi+\alpha \log \left(\mathrm{L}_{\mathrm{i}}\right)+\beta \log \left(\mathrm{N}_{\mathrm{i}}\right)+\gamma \log \left(\mathrm{K}_{\mathrm{i}}\right)+\mathrm{C}_{\mathrm{i}}
$$

Where the necessary conditions to apply OLS are:

$$
\mathrm{E}\left(\mathrm{C}_{\mathrm{i}}\right)=0, \operatorname{Cov}\left(\mathrm{L}_{\mathrm{i}}, \mathrm{C}_{\mathrm{i}}\right)=0, \operatorname{Cov}\left(\mathrm{N}_{\mathrm{i}}, \mathrm{C}_{\mathrm{i}}\right)=0, \operatorname{Cov}\left(\mathrm{K}_{\mathrm{i}}, \mathrm{C}_{\mathrm{i}}\right)=0,
$$

However, in the present case, the variables $\mathrm{Y}$ and $\mathrm{K}$ are potentially correlated thereby the estimation through OLS is not directly applicable otherwise the obtained coefficients would be biased and inconsistent because $\mathrm{Ki}$ and Cimay be correlated thereby violating the condition of $[\mathrm{Cov}(\mathrm{Ki}, \mathrm{Ci})=0]$. Brückner (2012) also discussed the issue of omitted variables and impact in instrumental variables. To overcome this issue, one alternative is to use Fi (Fertilizer) as an instrumental variable which satisfies the following conditions:

$\operatorname{Cov}\left(F_{i}, \epsilon_{j}\right)=0$ and

$\mathrm{K}_{\mathrm{i}}=\beta_{0}+\beta_{1} \mathrm{~F}_{\mathrm{i}}+$ ui where $\mathrm{E}$ (ui) $=\mathrm{o}$ and $\operatorname{Cov}\left(\mathrm{Fi}, \mathrm{u}_{\mathrm{i}}\right)=0$

So, the estimator of instrumental variable of $\gamma$ given as follows:

$$
\hat{\gamma}=\left(N^{-1} \sum_{i=1}^{N} f_{i}^{\prime} x_{i}\right)^{-1}\left(N^{-1} \sum_{i=1}^{N} f_{i}^{\prime} y_{i}\right)=\left(F^{\prime} X\right)^{-1} F^{\prime} Y
$$

Where $\mathrm{F}$ and $\mathrm{X}$ are $\mathrm{N} * \mathrm{~K}$ data matrices and $\mathrm{Y}$ is $\mathrm{N} * 1$ data vector on $\mathrm{Yi}$. Since, $\gamma=\left[\left(z^{\prime} x\right)\right]^{-1} E\left(z^{\prime} y\right), \gamma$ is a consistent estimator of $\gamma$. The system has a unique solution if the $\mathrm{K} * \mathrm{~K}$ matrix $\mathrm{E}\left(\mathrm{z}^{\prime} \mathrm{x}\right)$ has full rank $\mathrm{K}$. Therefore, the model with instrumental variable for estimation is as follows;

$$
\log (\mathrm{Yi})=\pi+\alpha \log (\mathrm{Li})+\beta \log (\mathrm{Ni})+\gamma \log (\mathrm{Fi})+\mathrm{Ci}
$$

Where $\mathrm{Fi}$ is the instrument for $\mathrm{Ki}$ while the results of this model are presented as:

\begin{tabular}{|l|l|l|}
$\begin{array}{l}\log (\mathrm{Yi}) \\
\log (\mathrm{Fi})\end{array}$ & $=8.998+0.555 \log (\mathrm{Li})+0.293 \log (\mathrm{Ni})+0.218 \log (\mathrm{KI})+0.357$ \\
\hline Adjusted R2 $=0.835$ & F-Statistics $=102.359$ & Prob (f-Stat $)=0.000$ \\
\hline
\end{tabular}

All variables are significant at 1 percent.

Authors' estimation

The results show that agricultural land is accounted for the largest share in the agricultural production whereas fertilizer is the second most contributing factor for the same. The results show that labor contributes more than physical capital for agricultural production. Another way to address the endogeniety problem is to use two stage least square (2SLS) method. The necessary details of 2SLS are presented as follows: 


\section{Two stage least square}

In case of violating the assumption of $\left[\operatorname{Cov}\left(\mathrm{K}_{\mathrm{i}}, \mathrm{C}_{\mathrm{i}}\right)=0\right]$, an special case of instrumental variable (I.V) regression commonly termed as two stage least square method (2SLS) can be used. In order to satisfy the order condition, we have used 4 instrumental variables including constant term. The instrumental variables must be orthogonal to the error term as well as correlated with the endogenous variable/s which is termed as relevance condition in order to be asymptotically consistent. The validity of the instruments is tested though Sargan test as proposed by Sargan (1964) and all of the instruments are found to be valid. Theoretically, if $Z$ is the matrix of instrumental variables whereas $y$ and $X$ are the dependent and independent variables respectively, then the coefficients obtained through 2SLS are given by:

$$
\gamma_{\text {TSLS }}=\left(X^{\prime} Z\left(Z^{\prime} Z\right)^{-1} Z^{\prime} X\right)^{-1} X^{\prime} Z\left(Z^{\prime} Z\right)^{-1} Z^{\prime} y
$$

The model used for the 2SLS is given as follows:

$$
\log \left(\mathrm{Y}_{\mathrm{i}}\right)=\pi+\alpha \log \left(\mathrm{L}_{\mathrm{i}}\right)+\beta \log \left(\mathrm{N}_{\mathrm{i}}\right)+\gamma \log \left(\mathrm{K}_{\mathrm{i}}\right)+\mathrm{C}_{\mathrm{i}}
$$

The $\log (\mathrm{F}), \log (\mathrm{H}), \log (\mathrm{L})$ and Constant term are used as instruments. Here Hi is used as a proxy for human capital captured through gross enrolment rate at secondary level in the country i. Data source and time for Hi is same as for other variables. The results of two stage least square is presented in the following table along with the coefficients obtained through ordinary least square, and instrumental variable approach in order to compare the results obtained through different approaches.

Table 2 Comparison of coefficients obtained through different approaches

\begin{tabular}{|c|c|c|c|}
\hline Variables & OLS & IV & 2SLS \\
\hline $\mathrm{L}$ & $0.531^{*}$ & $0.555^{*}$ & 0.074 \\
\hline $\mathrm{N}$ & $0.304^{*}$ & $0.293^{*}$ & $0.965^{*}$ \\
\hline $\mathrm{K}$ & $0.381^{*}$ & $0.218^{*}$ & $0.844^{*}$ \\
\hline $\mathrm{F}$ & --- & $0.357^{*}$ & --- \\
\hline Constant & 9.815 & 8.998 & 3.443 \\
\hline Adjusted R2 & 0.790 & 0.835 & 0.487 \\
\hline F-Stat & 101.390 & 102.359 & 40.585 \\
\hline Prob (f-stat) & 0.000 & 0.000 & 0.000 \\
\hline
\end{tabular}

Variables are in log form

Instrument list: C LOG(F) LOG(H) LOG(L) in 2SLS. 
The coefficients of land, labor and capital obtained from OLS are found to be positively and significantly related with agricultural production however, they are inconsistent because of endogeniety in the equation-1.Lin (1987) discussed the coefficients obtained from OLS and 2SLS are compared and found to be different. In case of I.V approach, the productivity of land is found to be the most contributing factor whereas the role of fertilizer is the second most contributing factor. It is found that the role of agricultural labor is more contributing then the role of physical capital used in the agricultural sector. The coefficient of land obtained through two stage least square (TSLS) is found to be statistically insignificant which might be because of mass availability of agricultural land available in most of the countries in the sample. Similar to the coefficient of labor estimated through I.V approach, the coefficient of labor is found to be more important for agricultural production then the use of capital even though the coefficients of labor and capital through both (I.V and 2SLS) approaches are found to be statistically significant.

\section{CONCLUSION}

In most of the studies where different types of production functions were used in order to estimate the relative importance of different factors in agricultural production, the possible endogeniety in the production function reduces the reliability of estimated coefficients. In the standard form of such functions, labor and capital are taken as inputs for agricultural production however, more investment is associated with more income (output). If investment is connected with production in this way, then the coefficients estimated through ordinary least square would be inconsistent and the conclusions drawn on the basis of that function would be less justifiable.

The study found that physical capital is endogenous and the estimated coefficients of equation 1.1 are inconsistent. As an alternative of OLS, I.V approach and 2SLS are adopted and the results are compared with the inconsistent coefficients of equation 1.1. Even though the results of I.V approach and 2SLS are found to be slightly different however, the obtained coefficients through both approaches are more reliable then the coefficients obtained through OLS in this area.Researchers like Bascle (2008); Semadeni et al. (2014); Cawley and Meyerhoefer(2012); and Roberts et al. (2013)has found the existence of endogeneity and addressing its causal relationships through I.V. approach a better way in other areas too. That is why, it is suggested that the approaches like I.V approach, 2SLS and GMM should be employed in the studies pertaining to this area of research and can be applied in other areas too.

\section{REFERENCES}

Alauddin, M., Headey, D. and Rao, D.S., (2005). Explaining Agricultural Productivity Levels and Growth: An International Perspective. Centre for Efficiency and Productivity Analysis Working Paper Series No. 02/2005.

Allen, S.L. and Qaim, M., (2012). Agricultural productivity and public expenditures in sub-saharan Africa, IFPRI discussion papers 1173, International Food Policy Research Institute (IFPRI).

Bascle, G., (2008). Controlling for endogeneity with instrumental variables in 
strategic management research, Strategic Organization, 6(3), 285-327.

Bhattacharjee, J. (1955). Resource Use and Productivity in World Agriculture. Journal of Farm Economics, 37(1), 57-71.

Brückner, M., (2012). Economic growth, size of the agricultural sector, and urbanization in Africa, Journal of Urban Economics, 71(1), 26-36.

CawleyJ. andMeyerhoefer C.. (2012). The medical care costs of obesity: An instrumental variables approach, Journal of Health Economics, 31(1), 219-230.

Davidson, R. and MacKinnon, J., (1993). Estimation and Inference in Econometrics,

OUP Catalogue: Oxford University Press, https://EconPapers.repec.org/ RePEc:oxp:obooks:9780195060119.

Davidson, R., \& MacKinnon, J. (1989). Testing for Consistency using Artificial Regressions. Econometric Theory, 5(3), 363-384.

Down, C.G., \& Stocks, J. (1977). Environmental Impact of Mining, Applied Science Publishers Ltd. New York: John Wiley \& Sons,

Felloni F., Wahl T., Wandschneider P., and Gilbert J., (2001). Infrastructure and agricultural production: cross-country evidence and implications for China.

IMPACT Center, TWP-2001-103, Washington State University.

Fulginiti, L. E and Perrin, R. K (1998). Agricultural productivity in developing countries. Agricultural Economics, 19, 45-51.

Gollin, D., Lagakos, D., \& Waugh, M. (2014). The agricultural productivity gap. Journal of Economics, 129(2), 939-993.

Hausman, Jerry, (1978), Specification Tests in Econometrics,Econometrica, 46(6), 1251-1271.

Hayami, Y., \&Ruttan, V. (1970). Agricultural Productivity Differences among Countries, The American Economic Review, 60(5), 895-911.

Hayami, Y., (1969). Sources of Agricultural Productivity Gap Among Selected Countries, American Journal of Agricultural Economics, 51(3), 564-575.

Hayami, Y., and Inagi, K. (1969). International Comparisons of Agricultural Productivity, Farm Economist, 11, 407-419.

Hayami, Y., Ruttan, V. W., et al. (1971). Agricultural development: an international perspective. Baltimore, Md/London: The Johns Hopkins Press.

Headey, D., Alauddin, M and Rao, D. S. P (2010). Explaining agricultural productivity growth: an international perspective. Agricultural Economics 41, $1-14$.

Headey, D., Alauddin, M., and Rao, D.S., (2010). Explaining agricultural productivity growth: an international perspective, Agricultural Economics, 41, $1-14$.

Heady, E. O and Dillon, J. L(1961). Agricultural Production Functions. Ames: Iowa State, University Press.

Heady, E. O. (1946). Production functions from a random sample of farms. Journal of Farm Economics 28(4), 989-1004.

Kawagoe, T., Hayami, Y. and Ruttan, V., (1985), The Intercountry Agricultural Production Function and Productivity Differences Among Countries, Journal of Development Economics, 19, 113-32.

Lagakos, D., and Waugh, E.M. (2013). Selection, Agriculture, and Cross-Country Productivity Differences, American Economic Review, 103(2): 948-980.

Lau, Lawrence, and Pan A. Yotopoulos. (1989). The Meta-Production Function Approach to Technological Change in World Agriculture, Journal of 
Development Economics, 31(2), 241-269.

Lin, J. (1987). The Household Responsibility System Reform in China: A Peasant's Institutional Choice. American Journal of Agricultural Economics, 69(2), 410415.

Mundlak, Y., Butzer, R and Larson, D (2008). Heterogeneous Technology and Panel Data: The Case of the Agricultural Production Function. Policy Research Working Paper 4536, The World Bank Development Research Group, Sustainable Rural and Urban Development Team.

Mundlak, Y., Butzer, R., and Larson, D. F. (2012). Heterogeneous technology and panel data: The case of the agricultural production function. Journal of Development Economics, 99(1), 139-149.

Mundlak, Y., Larson, D., \&Butzer, R. (1999). Rethinking within and between Regressions: The Case of Agricultural Production Functions. AnnalesD'Économie Et De Statistique, (55/56), 475-501.

Roberts, M.R., and T.M. Whited (2013). Endogeneity in Empirical. Corporate Finance, Handbook of the Economics of Finance, Chapter 7, 2A, 493-572.

Sargan, J. D., (1964). Wages and Prices in the United Kingdom: A study in Econometric Methodology in P.E. Hart, G. Mills and J. K. Whitaker (eds.), Econometric Analysis for National Economic Planning, London: Butterworths. 25-63.

Sovey, A. J., \& Green, D. P. (2011). Instrumental variables estimation in political science: A readers' guide. American Journal of Political Science, 55(1), 188200.

Semadeni, M., Withers, M.C. and Certo, T.S. (2014). The perils of endogeneity and instrumental variables in strategy research: Understanding through simulations, Strategic Management Journal, 35(7), 1070-1079.

Trueblood, M.A. and Ruttan, V.W., (1995). A Comparison of Multifactor Productivity, Calculation of the US Agricultural Sector. Journal of Productivity Analysis, 6, 321-332.

Vollrath, D. (2007) Land distribution and international agricultural productivity. American Journal of Agricultural Economics, 89(1), 202-216.

Winters, P., Essam, T., Zezza, A., Davis, B., and Carletto. C. (2010). Patterns of Rural Development: A Cross-Country Comparison Using Microeconomic Data, Journal of Agricultural Economics, 61(3), 628-651. 
IBT Journal of Business Studies (IBT-JBS) Volume 15 Issue 2 December 2019

\section{APPENDIX:}

List of Countries:

\begin{tabular}{|c|c|c|c|c|c|}
\hline Number & Country & Number & Country & Number & Country \\
\hline 1 & Albania & 28 & Iran, Islamic Rep. & 55 & Poland \\
\hline 2 & Algeria & 29 & Iraq & 56 & Portugal \\
\hline 3 & Argentina & 30 & Ireland & 57 & Romania \\
\hline 4 & Armenia & 31 & Italy & 58 & Russian Federation \\
\hline 5 & Austria & 32 & Japan & 59 & Rwanda \\
\hline 6 & Azerbaijan & 33 & Jordan & 60 & Samoa \\
\hline 7 & Brazil & 34 & Kazakhstan & 61 & Senegal \\
\hline 8 & Bulgaria & 35 & Kenya & 62 & Serbia \\
\hline 9 & Canada & 36 & Korea, Rep. & 63 & Slovak Republic \\
\hline 10 & Chile & 37 & Kuwait & 64 & Slovenia \\
\hline 11 & China & 38 & Kyrgyz Republic & 65 & Spain \\
\hline 12 & Croatia & 39 & Latvia & 66 & Suriname \\
\hline 13 & Cuba & 40 & Lithuania & 67 & Sweden \\
\hline 14 & Cyprus & 41 & Luxembourg & 68 & Switzerland \\
\hline 15 & $\begin{array}{l}\text { Czech } \\
\text { Republic }\end{array}$ & 42 & Macedonia, FYR & 69 & $\begin{array}{l}\text { Syrian Arab } \\
\text { Republic }\end{array}$ \\
\hline 16 & Denmark & 43 & Malta & 70 & Tajikistan \\
\hline 17 & $\begin{array}{l}\text { Dominican } \\
\text { Republic }\end{array}$ & 44 & Mexico & 71 & Tanzania \\
\hline 18 & Ecuador & 45 & Moldova & 72 & Thailand \\
\hline 19 & $\begin{array}{l}\text { Egypt, Arab } \\
\text { Rep. }\end{array}$ & 46 & Nepal & 73 & Togo \\
\hline
\end{tabular}


IBT Journal of Business Studies (IBT-JBS) Volume 15 Issue 2 December 2019

\begin{tabular}{|l|l|l|l|l|l|}
\hline 20 & Estonia & 47 & Netherlands & 74 & Tonga \\
\hline 21 & Finland & 48 & North America & 75 & $\begin{array}{l}\text { Trinidad and } \\
\text { Tobago }\end{array}$ \\
\hline 22 & France & 49 & Norway & 76 & Turkey \\
\hline 23 & Georgia & 50 & Oman & 77 & Ukraine \\
\hline 24 & Germany & 51 & Pakistan & 78 & $\begin{array}{l}\text { United Arab } \\
\text { Emirates }\end{array}$ \\
\hline 25 & Honduras & 52 & Panama & 79 & United States \\
\hline 26 & Hungary & 53 & Paraguay & 80 & Uruguay \\
\hline 27 & India & 54 & Philippines & 81 & Vietnam \\
\hline
\end{tabular}

